\title{
Wear Characteristics of Hardfacing Coatings Obtained by Tungsten Inert Gas Method
}

\author{
Krzysztof Dziedzic", Jerzy Józwik², Marcin Barszcz'1, Konrad Gauda ${ }^{3}$ \\ 1 Lublin University of Technology, Electrical Engineering and Computer Science Faculty, Institute of Computer \\ Science, Nadbystrzycka38, Lublin 20-618, Poland \\ ${ }^{2}$ Lublin University of Technology, Mechanical Engineering Faculty, Department of Production Engineering, 36 \\ Nadbystrzycka, Lublin 20-618, Poland \\ ${ }^{3}$ University of Economics and Innovation in Lublin, Transport and Computer Science Faculty, Projektowa 4, \\ Lublin 20-209, Poland \\ *Corresponding author's e-mail: k.dziedzic@pollub.pl
}

\begin{abstract}
This paper evaluates the wear characteristics of hardfacing coatings. Regenerative hardfacing coatings were applied with the TIG (Tungsten Inert Gas) method. The solid welding wires were used to obtain the coatings marked as: EL-500 HB, EL-650 HB, and EL-3348. The tribological analysis of samples was conducted at room temperature. The wear rate was evaluated with a THT 1000 Anton Parr ball-on-disc tribotester, in accordance with the ASTM G-133 standard. The counterbody (static partner) consisted of balls with the diameter of 6 mm made of A12O3. The test was performed with the sliding speed of the friction pair $0.4 \mathrm{~m} / \mathrm{s}$, track radius $10 \mathrm{~mm}$, normal load $20 \mathrm{~N}$, acquisition rate $10 \mathrm{~Hz}$ and sliding distance $2000 \mathrm{~m}$. During the test, the friction coefficient and wear rate were recorded. The multi-criteria assessment of the construction materials discussed, while taking into account five criteria, showed that EL-3348 HB is the best material. Computer applications were used for multi-criteria assessment and statistical processing of data.
\end{abstract}

Keywords: coatings, hardfacing, welding, wear.

\section{INTRODUCTION}

The wear of working elements and machine parts, due to the friction processes, is still one of the basic factors of damage and failure of the machines used in industry. This is related to the production downtime needed to remove the failure, which causes a rapid increase in the costs incurred by companies. Very often, the costs of machine downtime many times exceed the costs of materials and labour. Other failure factors include corrosion and deformations. Numerous new and more effective methods of eliminating or reducing the wear of the operating machine elements have been developed for many years. Modern industry places high demand on it. The surface layer of working machine components has an impact on the service life. Modern surface engineering methods focus on changing its properties most often by hardening or reconstructing the worn layer [1]. The process of wear of elements and machine parts often occurs under the conditions of interaction of external forces such as: mechanical and thermal load as well as the chemical impact on the environment. In practice, the wear is the result of interaction of external extortions with the dominant role of the factor, the determination of which allows its proper prevention. Hence, the wear mechanisms are very complex. They contain many interconnected factors, the intensity of which depends on the working environment of machine elements as well as on the operating parameters. The ability to minimize wear directly results from the definition of wear resistance (absolute resistance). It should be aimed to limit the value of wear or intensity of wear. In order 
to effectively counteract the destructive processes determining the durability of a given friction pair, one should strive to learn about the mechanisms and specificity of leading wear processes $[2 \div 4]$.

In industrial applications, the materials based on iron $(\mathrm{Fe})$ are most commonly used to obtain hard welded layer [5]. Usually, they are characterized by lower purchase costs and good tribological properties. Good tribological properties characterize the alloys that have found wide application in industry such as: $\mathrm{Fe}-\mathrm{Cr}-\mathrm{C}, \mathrm{Fe}-$ $\mathrm{C}-\mathrm{B}, \mathrm{Fe}-\mathrm{C}-\mathrm{Mn}-\mathrm{C}, \mathrm{Fe}-\mathrm{Cr}-\mathrm{C}-\mathrm{B}, \mathrm{Fe}-\mathrm{Mn}-\mathrm{C}-\mathrm{B}$, $\mathrm{Fe}-\mathrm{Cr}-\mathrm{C}-\mathrm{Nb} / \mathrm{Ti}[6 \div 8]$. Base alloys are modified with various elements to improve the tribological properties [9]. This causes precipitation of hard phases in the obtained coatings, usually carbides and borides $[10 \div 12]$. The phases desired in microstructure are as follows: $\mathrm{WC}, \mathrm{TiC}, \mathrm{SiC}, \mathrm{Cr}_{7} \mathrm{C}_{3}$, $\mathrm{Fe}_{3} \mathrm{C}, \mathrm{FeB}$, and $\mathrm{Fe}_{2} \mathrm{~B}$. The alloying elements added to obtain these phases include such elements as: $\mathrm{Ti}, \mathrm{Nb}, \mathrm{Cr}, \mathrm{V}, \mathrm{Mo}, \mathrm{W}$, and $\mathrm{B}[13,14]$. Modification of the microstructure affects the change of mechanical properties of hard coatings, which in turn affects the improvement of tribological properties. Other wear-resistant alloys often used in industry are nickel (Ni) and cobalt (Co) alloys [15:17]. These materials are used for the regeneration of working elements operating under heavy loads, very often under abrasive conditions. They are used in mining, agricultural, recycling and machine industries.

Currently, hardfacing is one of the most commonly used methods for obtaining hard and wear-resistant $\mathrm{Fe}$-based layers. It involves applying a coating with higher hardness and good resistance to wear and corrosion on the material with lower hardness and poorer mechanical properties. There are three basic zones formed as a result of hardfacing: the base material (core), the transition zone (heat-affected zone) and the coating of the welded material. The hardfacing method is used to apply coating at the stage of production of new parts in order to increase their wear resistance or to regenerate the already used ones. Regenerative hardfacing very often allows restoring geometry and obtaining the operation properties similar to or even higher than welded elements. Several layers are usually applied, which are then often machined. Most of the modern welding techniques can be used in hardfacing. Good results are achieved using the Gas Metal Arc Welding (GMAWX) and tungsten insert gas (TIG). Plasma and laser hardfacing methods are also among the modern hardfacing techniques. The success of the hardfacing process is most often influenced by factors such as: the type of material on which the hardfacing is performed, type of material used for hardfacing, the hardfacing method, parameters of the hardfacing process and the shielding gas used $[18,19]$. It is very important to evaluate the resulting coatings and the presence of defects in them. Cracks or pores may reduce the service value of the hardfacing coat or completely prevent its application. Currently, the computer microtomography method is used to assess the welding defects, both qualitative and quantitative. This enables to identify and assess the impact of the defects arising during hardfacing on the usability of coatings [20].

The effective methods for multi-criteria evaluation of the created design solutions or created new materials and the choice of the best solution without the scalarisation of the analysed set of criteria describing properties or performance are described in $[21,22]$.

\section{MATERIALS AND METHODS}

Three welding materials were used to obtain wear-resistant coatings: EL-500 HB, EL-650 HB, EL-3348. Material EL-3348 is an ironbased alloy that has the form of a solid wire. It is intended for the regeneration of high-speed steels characterized by high impact resistance. The chemical composition is as follows: (\%wt.) $\mathrm{C}-1.0, \mathrm{Si}-0.3, \mathrm{Mn}-0.3, \mathrm{Cr}-4.0, \mathrm{Mo}-8.3, \mathrm{~V}$ $-1.90, \mathrm{~W}-1.80$. The achievable coating hardness given by the manufacturer is 57-62 HRC. The second material used was EL-650 HB. It is an iron-based alloy that has the form of a solid wire. Its basic purpose is hardfacing of the working elements subjected to heat, exposed to abrasive wear, impacts and temperatures up to $500^{\circ} \mathrm{C}$. The chemical composition is as follows (\%wt.) C - 0.4, Si - 1.1, Mn - 0.4, Cr - 5.30, $\mathrm{Mo}-1.4, \mathrm{~V}-0.35, \mathrm{~W}-1.35$. The obtainable hardness of coatings for this material given by the manufacturer is 57-60 HRC. The third material used was EL-500 HB. It is an iron-based alloy that also had the form of a solid wire. Its main purpose is hardfacing of the elements exposed to abrasive wear and pressure, made of structural steel, cast steel, and manganese steel. The chemical composition is as follows (\%wt.) $\mathrm{C}-1.15, \mathrm{Mn}-1.95, \mathrm{Cr}-1.90$. The coating hardness achievable for this material is 52 HRC. 
Table 1. Parameters of the hardfacing process

\begin{tabular}{|c|c|c|c|}
\hline Arc voltage & $\begin{array}{c}\text { Hardfacing } \\
\text { current }\end{array}$ & Polarization & $\begin{array}{c}\text { Shielding } \\
\text { gas }\end{array}$ \\
\hline $18 \mathrm{~V}$ & $80 \mathrm{~A}$ & + & $99.9 \%$ Argon \\
\hline
\end{tabular}

As a method of applying wear-resistant coatings, the model of welding with a non-melting TIG electrode was chosen. The material, on which the coatings were applied was C45 steel. It is a non-alloy quality steel for thermal improvement with the following chemical composition (\% wt.) $\mathrm{C}-0.42$ to $0.5, \mathrm{Mn}-0.5$ to $0.8, \mathrm{Si}-0.1$ to 0.4 , $\mathrm{Cr}-0.3, \mathrm{Mo}-0.1, \mathrm{Ni}-0.3$ and $\mathrm{Cu} 0.3$.

The TIG AC/DC ControlPro LORCH welding device was used as a welding station. The welding station is shown in Figure 1a. The coatings were welded on the face of a $60 \mathrm{~mm}$ diameter C45 steel cylinder. In order to obtain coatings with the compositions similar to those supplied by the manufacturer of welding materials, 4 layers of hardfacing were applied. The basic parameters of the hardfacing process are presented in Table 1.

Then, the welds were processed to the dimensions of the sample necessary to carry out the tribological tests. The front and side surfaces were rolled. The front surface was finished by grinding. The welds after machining are shown in Figure $1 \mathrm{~b}$. The disk-shaped sample was then cut off. In this way, samples with a diameter of $50 \mathrm{~mm}$ and a height of $10 \mathrm{~mm}$ were obtained.

The tribological (in-situ) tests were carried out to associate the ball-on-disc friction pair. The counter-sample in the form of a ball made of $\mathrm{Al} 2 \mathrm{O} 3 \mathrm{had}$ a diameter of $6 \mathrm{~mm}$. The tribological parameters measured and calculated during the tribological tests are the wear coefficients of cooperating ma-
Table 2. Tribological test parameters

\begin{tabular}{|c|c|c|c|}
\hline $\begin{array}{c}\text { Friction } \\
\text { path }\end{array}$ & $\begin{array}{c}\text { Rotational speed } \\
\text { of the disk }\end{array}$ & $\begin{array}{c}\text { Radius of } \\
\text { friction }\end{array}$ & Load \\
\hline $2000 \mathrm{~m}$ & $0.4 \mathrm{~m} / \mathrm{s}$ & $10 \mathrm{~mm}$ & $20 \mathrm{~N}$ \\
\hline
\end{tabular}

terials and friction coefficients. The tests were carried out on the THT 1000 Anton Parr tribotester together with the software enabling computer control as well as data acquisition and processing with the options of displaying and saving. The tests were carried out in compliance with the recommendations of the ASTM G133 standard.

The used parameters of tribological tests are listed in Table 2. The measurement data was recorded at a frequency of $10 \mathrm{HZ}$. Tests were repeated 3 times. The obtained results were processed statistically using computer applications.

Serving as a comparative measure of wear, which takes into account the load and the length of the stroke a new wear rate for a friction pair was calculated in compliance with ASTM G133 and with the use of the following equation (1).

$$
W_{d}=\frac{V_{f}}{F_{n} \times l}
$$

where: $W_{d}$ - is the wear rate; $V_{f}$ - is the wear volume; $F_{n}$ - is the loading force; $l-$ is the length of the stroke (distance).

The measure of the sample wear was a volumetric decrease, which occurred as a wear scar resulting from the interaction between the sample and the counterbody. For that purpose, using a contact profilometer Surtronic 3+, a profile area was measured perpendicularly to the sample wear scars. The measurements were performed on the perimeter of the sample (at ten points). The length of the stroke was $4 \mathrm{~mm}$.

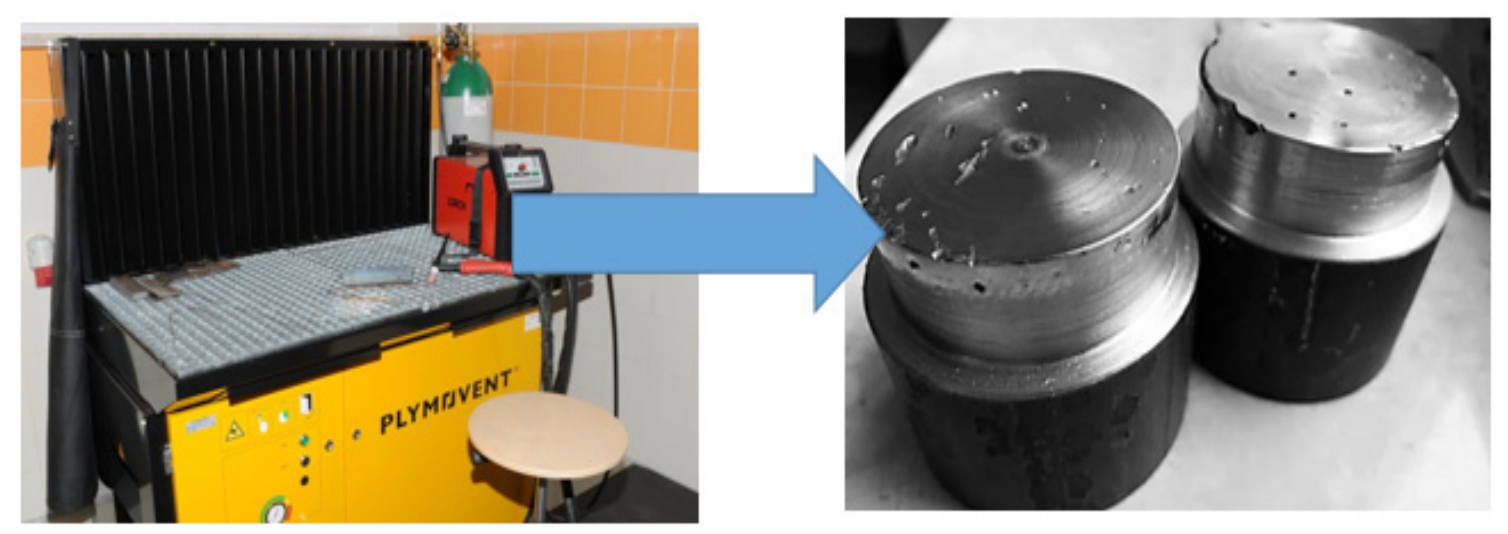

Fig. 1. Hardfacing of coatings a) hardfacing station, b) hardfacing of the sample after rolling and grinding the front surface 
The volumetric wear was specified as the product of the average value of the sample wear area and the perimeter of a wear scar circle which appeared during the ball-on-disc test. The following equation was applied (2).

$$
V_{f}=A \times L
$$

where: $V_{f}$-is the wear volume; $A$-is the average cross-sectional area of the track; $L-$ is the length of the stroke.

The hardness measurements were carried out by means of Wolpert 600MRD micro hardness tester using the HRC method. Vickers Hardness HV10 were taken by Prauftechnik KB-10 micro hardness tester. Hardness was measured on the front surface of the sample. The tests were repeated three times. For comparison, HV10 microhardness was converted to hardness in HRC using appropriate tables.

The multi-criteria evaluation of the quality of materials was carried out on a five-element set of criteria; the first three of which were minimised, while the next two were maximised. In the first stage, a subset of non-dominated solutions was determined, and then a compromise solution was determined using the min-max method with weights based on the Chebyshev's metrics. Criterion 1 - wear rate, Criterion 2 - friction coefficient max., Criterion 3 - friction coefficient mean, Criterion 4 - hardness HRC, Criterion 5 - hardness $\mathrm{VH} \rightarrow \mathrm{HRC}$.

$$
p[\boldsymbol{F}(\mathbf{x})]=\min _{n \in N} \max _{j \in J}\left\{\omega_{j} \frac{\left|F_{j}^{\mathbf{o}}-F_{j}^{n}\right|}{\left|F_{j}^{\mathbf{o}}\right|}\right\}
$$

where: $\omega_{j}$ - "weight" of the $j$-th criterion, the sum of all weights equals $1 ; j, n$-indexes of the criteria and non-dominant solutions considered, $F_{j}^{o}-j$-th component of the ideal vector.

\section{RESULT AND DISCUSSION}

The present study is concentrated on the friction and wear characteristic of hardfacing coatings. Before the friction Ra roughness parameter for samples was $0.59 \mu \mathrm{m}$. The wear process depends on many factors such as the pair friction material, surface roughness, surface hardness, contact temperature, sliding velocity and load. Figure 2 presents hardness from the top surface of the hardfacing coatings. The hardfacing made from EL-3348 has the higher hardness value of $65 \mathrm{HRC}$. EL-500 $\mathrm{HB}$ and EL-650 HB have a lower hardness.

The load and friction distance were the major factors taken into account while calculating and characterising wear volume. Having employed a comparative measure of wear based on the load and friction distance, wear rate for a friction pair was calculated using equation (1). Figure 2 presents the wear rate of the tribological experiment for the load of $20 \mathrm{~N}$. The wear rate value for the samples EL-3348 was $0,693 \times 10^{-5} \mathrm{~mm}^{3} \mathrm{~N}^{-1} \mathrm{~m}^{-1}$, for EL-650 was $1,113 \times 10^{-5} \mathrm{~mm}^{3} \mathrm{~N}^{-1} \mathrm{~m}^{-1}$ and for EL500 was $1,217 \times 10^{-5} \mathrm{~mm}^{3} \mathrm{~N}^{-1} \mathrm{~m}^{-1}$. As far as the counterbodies made from $\mathrm{Al}_{2} \mathrm{O}_{3}$ were concerned, for the EL-3348 was $4,129 \times 10^{-7} \mathrm{~mm}^{3} \mathrm{~N}^{-1} \mathrm{~m}^{-1}$, for EL-650 was $6,057 \times 10^{-7} \mathrm{~mm}^{3} \mathrm{~N}^{-1} \mathrm{~m}^{-1}$ and for EL-500 was $5,024 \times 10^{-7} \mathrm{~mm}^{3} \mathrm{~N}^{-1} \mathrm{~m}^{-1}$. Figure 3 also presents the

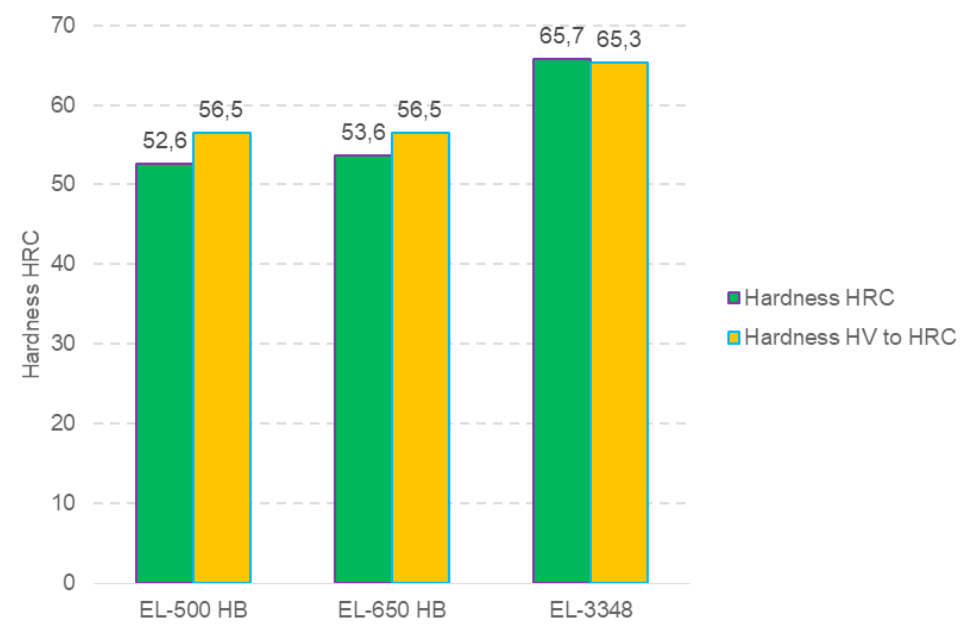

Fig. 2. Hardness from top surface of hardfacing coatings 


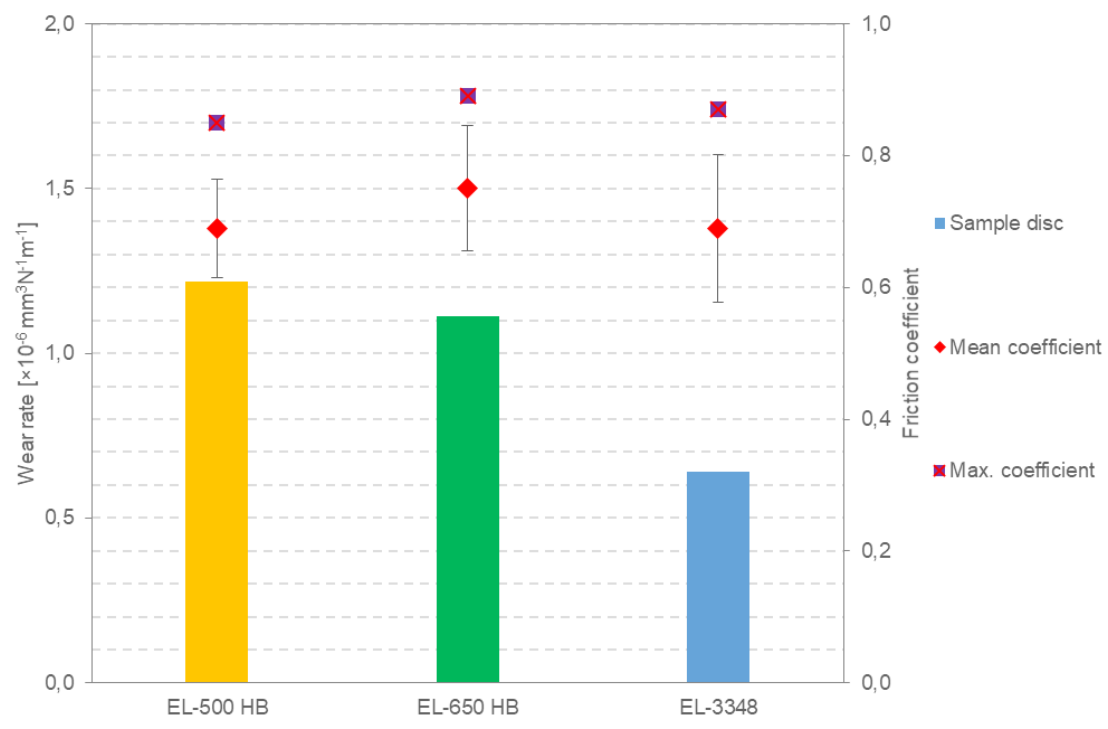

Fig. 3. Wear rate and friction coefficient

alterations of the mean and maximum coefficient. The mean friction coefficient for the samples EL3348 was 0.69 , the maximum one was 0.87 . For the samples EL-650 was higher 0.79, the maximum one was 0.89 . For the samples EL-500 was 0.69, the maximum one was 0.85 .

In the course of the conducted tribological tests, the friction coefficient changes were registered. Figure 4 demonstrates friction coefficient changes for the load of $20 \mathrm{~N}$ registered at a distance of $2000 \mathrm{~m}$.

A subset of non-dominated solutions counted 2 elements. It turned out that the EL-650 HB mate- rial has all of its properties worse than EL-3348, and therefore EL-650 HB was rejected. The ideal vector that is the reference point for the min-max method with weights is [0.639 0.85 0.69 65.7 65.3].

The analysis of belonging to individual elements of a subset of non-dominated solutions showed that components 2 and 3 belong to the EL-500 HB material, and 1, 3, 4 and 5 to material EL-3348. Component 3 has identical values for both materials. The composition of the ideal vector indicates that the EL-3348 material has a greater representation, which in a way makes it a more attractive solution. The confirmation of this

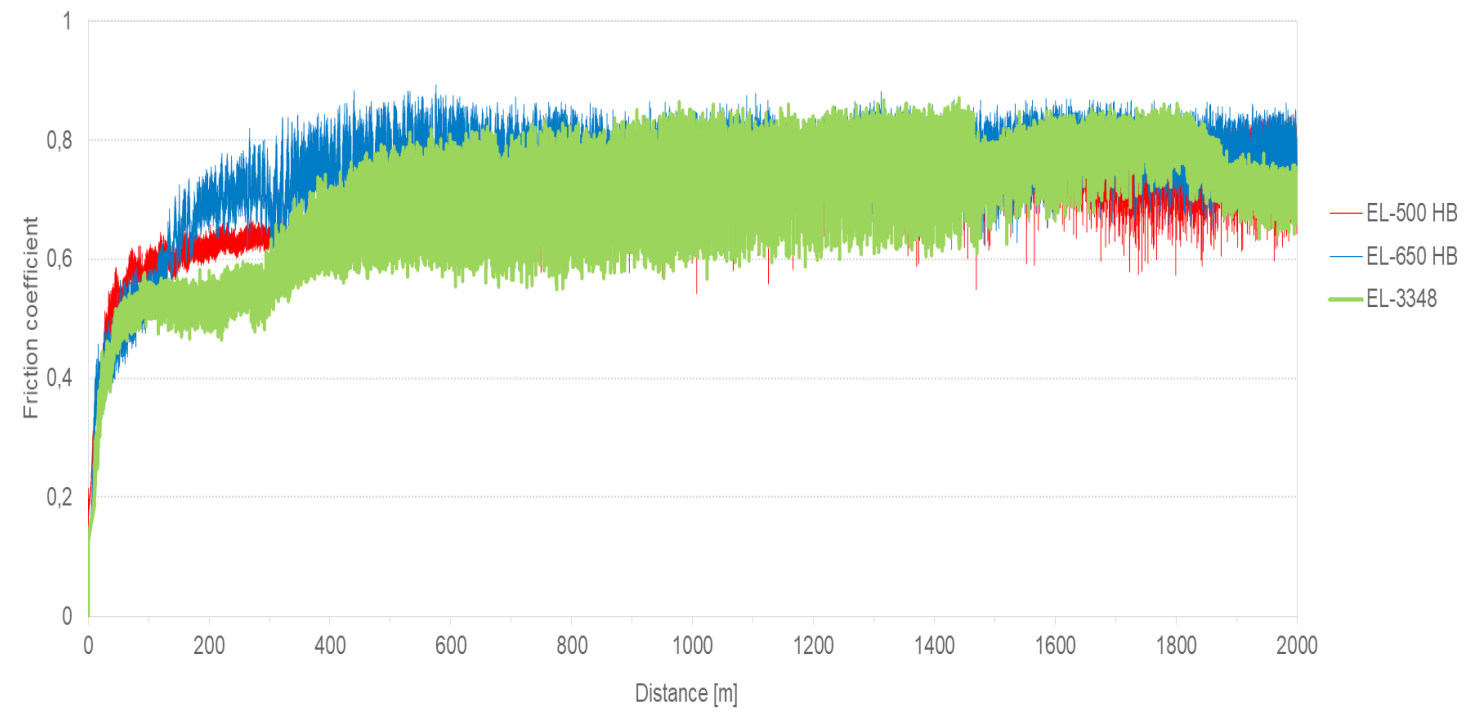

Fig. 4. Variation in the friction coefficients 
fact was obtained by designing a compromise solution. In the multi-criteria sense, the properties of material EL-3348 exceed those of EL-500 HB.

\section{CONCLUSIONS}

The main results can be summarized as follows:

1. The TIG method (tungsten inert gas) is useful for obtaining good wear resistant coatings. Arc voltage and current employed were $18 \mathrm{~V}$ and 80 A respectively (positive polarity). The protective gas was Argon with purity of $99.9 \%$.

2 . The results also showed that the mean friction coefficient was 0.69 for EL-3348 and EL-500 HB. For EL-650 HB it was higher -0.79 .

3. The multi-criteria analysis, taking into account a five-element set of criteria, showed that the EL-3348 material is characterised by better properties than the other materials tested. The wear rate for samples with coatings obtained from EL-3348 was the lowest and reached $0.64 \times 10^{-5} \mathrm{~mm}^{3} \mathrm{~N}^{-1} \mathrm{~m}^{-1}$. These hardfacing coatings have good wear resistance.

4. The highest hardness value $65 \mathrm{HRC}$ is achieved by the hardfacing made from EL- 3348. It can be seen that the wear rate is the smallest for the sample with the highest hardness. Other samples show a similar relationship. The wear rate is higher for the EL-650 HB sample, which had lower hardness. The highest wear rate was for the EL-500 HB sample, where HRC hardness was the lowest. In the case of tested samples, the relationship between the weld hardness and the wear rate can be seen.

\section{REFERENCES}

1. Dziedzic K., Paszeczko M., Barszcz M., Józwik J.B., Structure and construction assessment of the surface layer of hardfaced coating after friction. Advances Science and Technology Research Journal, 11, 2017, 253-260.

2. Tadeusz Burakowski, Tadeusz Wierzchon, Surface Engineering of Metals: Principles, Equipment, Technologies, Materials Science \& Technology, CRC Press, 1998.

3. Correa E. O., Alcantara N. G., Valeriano L. C., Barbedo N. D., Chaves R. R. The effect of microstructure on abrasive wear of a $\mathrm{Fe}-\mathrm{Cr}-\mathrm{C}-\mathrm{Nb}$ hardfacing alloy deposited by the open arc welding process, Surface \& Coatings Technology, 276, 2015, 479-484.
4. Pashechko M., Dziedzic K., Mendyk E., Jozwik J. Chemical and phase composition of the friction surfaces Fe-Mn-C-B-Si-Ni-Cr hardfacing coatings, Journal of Tribology-Transactions of the ASME, 140, 2018, 021302-1 - 021302-5.

5. Venkatesh B., Sriker K., Prabhakar VSV. Wear characteristics of hardfacing alloys: state-of-the-art, Procedia Materials Science, 10, 2015, 527 - 532.

6. Gualco A., Svoboda H., Surian E. Study of abrasive wear resistance of Fe-based nanostructured hardfacing, Wear, 360, 2016, 14-20.

7. Badisch E., Katsich C., Winkelmann H., Franek F., Roy M. Wear behaviour of hardfaced Fe-Cr-C alloy and austenitic steel under 2-body and 3-body conditions at elevated temperature, Tribology International, 43, 2010, 1234-1244.

8. Gualco A., Marini C., Svoboda H., Surian E. Wear Resistance of Fe-based Nanostructured Hardfacing, Procedia Materials Science, 8, 2015, 934 - 943.

9. Pashechko M., Lenik K., Segregation of atoms of the eutectic alloys $\mathrm{Fe}-\mathrm{Mn}-\mathrm{C}-\mathrm{B}-\mathrm{Si}-\mathrm{Ni}-\mathrm{Cr}$ at friction wear, Wear, 267, 2009, 1301-1304.

10. Chaidemenopoulos N.G., Psyllaki P.P., Pavlidou E., Vourlias G. Aspects on carbides transformations of Fe-based hardfacing deposits, Surface \& Coatings Technology, 357, 2019, 651-661.

11. Pawar S., Jha A. K., Mukhopadhyay G. Effect of different carbides on the wear resistance of Fe-based hardfacing alloys, International Journal of Refractory Metals \& Hard Materials, 78, 2019, 288-295.

12. Hornung J., Zikin A., Pichelbauer K., Kalin M., Kirchgaßner M. Influence of cooling speed on the microstructure and wear behaviour of hypereutectic $\mathrm{Fe}-\mathrm{Cr}-\mathrm{C}$ hardfacings, Materials Science and Engineering: A, 576, 2013, 243-251.

13. Yüksel N., Sahin S. Wear behavior-hardness-microstructure relation of $\mathrm{Fe}-\mathrm{Cr}-\mathrm{C}$ and $\mathrm{Fe}-\mathrm{Cr}-\mathrm{C}-\mathrm{B}$ based hardfacing alloys, Materials and Design, 58, 2014, 491-498.

14. Liu D., Liu R., Wei Y., Ma Y., Zhu K. Microstructure and wear properties of $\mathrm{Fe}-15 \mathrm{Cr}-2.5 \mathrm{Ti}-2 \mathrm{C}-\mathrm{xB}$ wt.\% hardfacing alloys. Applied Surface Science, 271, 2013, 253-259.

15. Da Silva L. J., D'oliveira A. NiCrSiBC coatings: Effect of dilution on microstructure and high temperature tribological behaviour, Wear, 350, 2016, 130-140.

16. Hakraborty G., Das C. R., Albert S. K., Bhaduri A. K., Murugesan S., Dasgupta A. Effect of Alloy 625 Buffer Layer on Hardfacing of Modified 9Cr-1Mo Steel Using Nickel Base Hardfacing Alloy, Journal of Materials Engineering and Performance, 25(4), 2016, 1663-1672.

17. Hanna M., Dybowski B., Moskal G. WC-Co coatings and sinters modified with nano-sized TiC mi- 
crostructure - quantitative evaluation, Advances Science and Technology Research Journal, 11(1), 2017, 220-231.

18. Cicic D. T., Rontescu C., Savulescu V., Bogatu A. $\mathrm{M}$. The processing method of the tungsten electrodes and the current type choice influence on the shape of the welding arc in tungsten inert gas welding (TIG), IOP Conf. Series: Materials Science and Engineering, 400, 2018, 022016.

19. Shahroozi A., Afsari A., Khakan B. Microstructure and mechanical properties investigation of Stellite 6 and Stellite 6/TiC coating on ASTM A105 steel produced by TIG welding process, Surface and Coatings Technology, 350, 2018, 648-658.
20. Józwik J. B., Dziedzic K., Krolczyk G. M., Ostrowski D., Usydus I. Assessment of internal defects of hardfacing coatings in regeneration of machine parts, Journal of Central South University, 25, 2018, 1144-1153.

21. Surdacki P., Montusiewicz J. Approach to multicriterion optimization of quench performance of superconducting winding, IEEE Transactions on Magnetics, 32(3) 1996, 1266-1269.

22. Pashechko M. I., Montusiewicz J. Evaluation of the Wear Resistance of Eutectic Coatings of the FeMn-C-B System Alloyed by Si, Ni, and Cr Using Multi-Criteria Analysis, Materials Science, 47(6), 2012, 813-821. 